\title{
Tales from within: Gifted Students' Lived Experiences with Teaching Practices in Regular Classrooms
}

\author{
Maria P. Gomez-Arizaga ${ }^{1, *}$, Marieta Valdivia-Lefort ${ }^{1}{ }^{(\mathbb{C}}$, Hernan Castillo-Hermosilla ${ }^{2} \mathbb{C}$, \\ Thomas P. Hébert ${ }^{3}$ and Maria Leonor Conejeros-Solar ${ }^{4}$ (D) \\ 1 Facultad de Educación, Universidad de los Andes, Santiago 7620001, Chile; marieta.constanza@gmail.com \\ 2 Dirección de Desarrollo Académico, Universidad Mayor, Santiago 7550263, Chile; hernan.castillo@umayor.cl \\ College of Education, University of South Carolina, Columbia, SC 29208, USA; thebert@sc.edu \\ 4 Escuela de Pedagogía, Pontificia Universidad Católica de Valparaíso, Valparaíso 2530388, Chile; \\ leonor.conejeros@pucv.cl \\ * Correspondence: mpgomez@uandes.cl
}

Received: 31 January 2020; Accepted: 9 May 2020; Published: 12 May 2020

\begin{abstract}
Gifted students in regular classrooms have fewer opportunities to develop activities that are based on their characteristics as learners and address their needs; however, many of them spend most of their school time in these classrooms. The results presented here were part of a 2-year qualitative project that analyzed 12 Chilean gifted students' lived experiences in regular classrooms by exploring the factors that foster and hinder their learning through the use of photos, focus groups, and interviews. The results showed students' discontent with the national curriculum and teaching practices related to rigidity, lack of meaning, and unchallenging assessments. Nevertheless, positive experiences were reported related to teaching strategies, especially when they add novelty and move away from traditional approaches. Waiting experiences were common, but were often seen by students as opportunities for creative production. Methods for engaging gifted students in their learning are highlighted.
\end{abstract}

Keywords: gifted students; lived experiences; qualitative research; regular classroom; teachers of the gifted; classroom teachers

\section{Introduction}

Some well-known myths revolve around gifted students, many of which have been disproved by researchers in the field. For example, a popular belief-now refuted by evidence-states that gifted children will be academically successful, so they do not need to be served by regular schools $[1,2]$. However, several researchers have found that when there are no appropriate learning conditions for the gifted, they tend to be less motivated toward schooling [3] and get bored in regular classrooms mainly due to the lack of cognitive challenges [4,5]. When their needs are not being met, some negative consequences can occur, such as underachievement, school attrition [6], and low self-concept [7], among others.

In recent decades, important efforts have been made worldwide to widen the spectrum of special needs in education policies. In Chile, extracurricular programs have been created to provide enrichment opportunities for gifted students; however, many of these occur outside the school system and only around $1 \%$ of the national gifted student population is able to attend these programs [8]. Therefore, most gifted students spend their educational time in regular mainstream classrooms.

Although educational provisions such as university-based programs have improved the work with gifted students, little is known about what happens every day in their mainstream education. Even though there is a wide array of literature and empirical evidence on how to provide effective 
services for gifted students to promote their engagement and learning, there is still a need for evidence about their lived experiences within the regular classroom $[9,10]$. It is critical to explore, understand, and describe gifted students' learning experiences within regular classrooms.

\section{Theoretical Background}

\subsection{Definition of Giftedness}

The concept of giftedness used for this research is the Differentiated Model of Giftedness and Talent [11], which conceptualizes giftedness as a continuous process toward talent development. Giftedness refers to the possession and use of high abilities (aptitudes or gifts) that are expressed naturally, at a level that places the gifted individual among the top $10 \%$ of their age group. Talent is defined as an outstanding expression of one or more abilities, systematically developed in at least one field of human activity. Talents emerge progressively according to the development of these superior natural abilities into well-trained skills for a specific human field of performance. However, without this developmental process, natural abilities could remain at the level of gifts and never transform into talents; therefore, according to this model, the school experience can be critical for talent development.

\subsection{Learning in Gifted Students}

Although gifted students can be very similar to their non-gifted peers in many aspects, overarching research has shown that the learning and personality traits of the gifted can be grouped into specific characteristics that are particular to these students [12]. For instance, they tend to develop complex relationships of ideas, theorization, and abstract concepts, and to be more flexible and open-minded, objective, facing problems with superior logical analysis $[13,14]$. Furthermore, some researchers have found that gifted students have a special interest in problem-solving activities [15], critical thinking, experimenting, and exploring. They enjoy creating alternative solutions to a problem and designing new and original ideas [16].

One of the most important findings about gifted students' learning has been that they need to be provided with a pedagogy that matches their characteristics [17]. However, the most common activities that occur in regular classrooms are those that reinforce memory, structure, objective fact-learning, and group projects, which do not satisfy gifted learners' needs because they tend to be more flexible and independent when working and learning [18].

\subsection{Gifted Students' Experiences with Teaching}

For gifted students to have favorable and enriched learning experiences in the classroom, they need to have a teacher that recognizes their unique needs and interests, and therefore tailors his or her teaching to address those characteristics. This practice has been known in the field as differentiation, a tool that is widely known but not always practiced [19], as teachers in mainstream classrooms do not know how to differentiate for learners with high abilities [20].

\subsubsection{Curriculum Content}

Given gifted students' characteristics and how they approach learning in regular classrooms, the content provided in the curriculum could be critical for them in terms of engagement and potential development [21]. In this sense, Little [22] argued that gifted students' needs, characteristics, interests, experiences, and personal values are often neglected in the curriculum content, leading them to become unmotivated and disengaged with the material.

In a study that compared the learning preferences of gifted and non-gifted students, Kanevsky [23] found that the complexity, relevance, and richness of the content knowledge was more salient to the gifted than to their peers, which is an indicator that gifted students did not want to simply comply with the curriculum. 


\subsubsection{Teaching Strategies and Learning Preferences}

According to O'Reilly [24], gifted students usually learn at a faster pace and do not require constant repetition. Therefore, the traditional implementation of the curriculum in schools could be seen as excessively repetitive and rigid by gifted students, when teaching strategies merely focus on reproducing the curriculum content [18]. Additionally, instructors tend to teach at a pace focused on the 'average' student, which does not consider different learning trajectories. Peine and Coleman [25] found that gifted students are faced with several waiting times and coped in different ways with waiting in class. This waiting time could translate into boredom (to do nothing) or an opportunity (to do something). Some of the 'doing' strategies used by students included writing, drawing, or daydreaming.

An important element to consider is how the implemented strategies and activities allow the students to find value in, and therefore to become more engaged with, the assigned task. This value can be crucial for gifted students, as achievement does not guarantee engagement; for instance, not finding meaning and value can translate into not completing certain tasks [26]. Some authors have differentiated between the outcome of the task (utility value) and how the activity can be valuable by itself (intrinsic value), leading to increased motivation and enjoyment [22-27]. In this sense, one way to achieve intrinsic value with gifted students is to incorporate their personal interests into activities to increase their engagement with a particular task. This tactic is a long-term approach that aims to develop intrinsic motivation by capturing individual or all students' attention [28].

Regarding the type of activities in which students engage, some studies have shown that gifted students tend to have different preferences from their non-gifted peers; however, this aspect can vary according to age, gender, and culture [23]. For example, some studies have found that gifted high school students displayed a greater preference toward open-ended tasks and problems with multiple answers [23], where they can display complex abilities and manage unstructured content [29]. On the other hand, the opportunity to experience 'doing things' through hands-on activities, was particularly relevant for gifted students in elementary and middle school [30-32].

The concept of challenge has also been widely debated among strategies to address gifted students' needs, particularly in the way that the absence of challenge can translate into lack of motivation, frustration, and even disengagement in the regular classroom [29]. Eddles-Hirsch, Vialle, McCormick, and Rogers [33] investigated gifted students' perceptions regarding challenging strategies and found that when students' needs were met through a variety of alternatives, they were highly satisfied with the level of challenge in their activities, especially when compared to past school experiences where they felt that everything was 'too easy'. A study conducted by Gallagher, Harradine, and Coleman [34] concluded that both content repetition and a slow pace of learning were problematic for students, even when there existed some level of challenge. Similarly, in the findings of Pereira and Gentry [31], students sometimes reported a lack of challenge in their classroom activities.

\subsubsection{Assessment}

Some researchers have found that assessment practices can also be critical to improving performance in gifted students in regular classrooms. Teachers need to adjust evaluations like tests and group work to promote specific aspects of giftedness, such as critical thinking, abstraction, and association between concepts [35-37]. Furthermore, challenge needs to be presented as a critical element when evaluating gifted students' performance within the regular classroom [38].

Although gifted students' perceptions of assessment practices in regular classrooms has not been widely explored, the study by Kanevsky [23] suggested that the concerns about evaluation practices are similar between gifted and non-gifted students; however, gifted students have a stronger inclination toward wanting to choose from different types of assessments to demonstrate their learning. 


\subsection{Students as Evaluators}

The idea of students being evaluators of the educational system and its practices has been conceptualized as student voice, a term coined more than two decades ago under the premise that students have a limited participation in their school experiences [39]. Some researchers have found benefits to incorporating students' voices regarding issues, such as improvement of teaching (i.e., strategies used), curriculum [40], students' autonomy, sense of belonging, competence [41], and engagement with their schools [42]. In gifted education, a study conducted by Gentry, Rizza, and Owen [43] showed significant differences between what teachers and gifted students reported regarding perceptions of what occurs in regular classrooms, highlighting the importance of considering more than 'one side of the story'. Hence, experiences, perspectives, and opinions of gifted students can be considered by teachers and practitioners, as these students often have a clear view of what they want and need for their learning [32].

\subsection{Chile: Educational System and Gifted Education}

The current educational model in Chile has its roots in the educational reform of 1981 and is recognized as one of the most socially segregated worldwide [44]. Broadly, the Chilean system is composed of three main school systems: (a) public, fully financed by the state; (b) voucher, co-financed by the state and the families; (c) private, fully and directly financed by families. Despite this differentiation, the SES composition of public and voucher schools can be very similar $[45,46]$. This model contributes to social segregation within the schools and creates academic gaps due to the differences in budget and incentives received, particularly affecting teachers who are pressured to achieve good performance on national and international standardized assessments [47].

Regarding special education, although several laws have been created to address learning needs and inclusion in Chile, none of these regulations are specifically related to gifted students. To address this scenario, the first university-based program for gifted students was created in 2001 to serve students from public schools. After its creation, several other university-based programs emerged, and some private and small initiatives also appeared [48]. Programs for gifted students are situated in regional universities and are partially funded by the Ministry of Education (MINEDUC) [49]. To become a participant, students must be enrolled in grades 5-9 and pass through different stages of identification, starting with a preliminary screening executed by teachers within schools. This process is followed by an identification phase at the centers where the Raven's Standard Progressive Matrices test is administered. Given the students' socioeconomic background, the 75th percentile is used as a cut-off in the Raven test, as stated by the MINEDUC [49]. Private initiatives use other identification instruments, such as the Weschler Intelligence Scale for Children (WISC).

Although efforts to establish adequate programming for Chilean gifted students have been made, there is no guarantee for sustained services for the gifted population at the school level. Thus, it is crucial to understand the complexities and intricacies of gifted students' experiences in regular classrooms, as these represent their predominant learning scenario. The purpose of this study was to explore gifted students' experiences in regular classrooms in order to understand the elements of the teaching process that can facilitate or hinder their learning. The questions that guided this research were the following:

What were the characteristics of teaching in regular classrooms that promoted positive learning experiences in gifted students?

In what ways did the teaching practices in regular classrooms hinder the learning process of gifted students?

\section{Methods}

The present study is a partial report of the results of a two-year research project that explored the lived experiences of Chilean gifted students in regular classrooms. The research was conducted 
under a qualitative approach to explore microsocial phenomena in-depth [50]. Thus, the aim was to understand the meaning of students' educational experiences through an analytical and interpretive process [51]. This design was also based on participatory action research (PAR) techniques, in which students become partners in the research process by providing first-hand exploration of the immediate social context in which they learn, and the research process is viewed as a co-construction between participants and researchers [52].

\subsection{Participants}

A purposeful sample was used in this study, which is typical in qualitative research for selecting cases that are rich in information. Because no formal gifted identification procedures exist in Chile within regular schools, the population of students prone to be selected were those who were already identified as gifted by extracurricular enrichment programs. These programs serve students from 7 th to 12th grade, mainly from public schools. However, there is also representation from gifted students who come from subsidized schools classified as 'vulnerable' based on their families' SES. All the schools represented in the sample, regardless of their type (public or subsidized), are between $73 \%$ and $95 \%$ in the IVE-SINAE index presented by the JUNAEB (National Board of School Aid and Scholarships). This measure, which has a maximum index of $100 \%$ (highest level of vulnerability), describes the educational vulnerability of schools based on socioeconomic and socio-educational aspects.

The sample was therefore comprised of twelve middle and high school gifted students from nine schools located in two regions of the country. The criteria for inclusion were: (a) sex, to have the same proportion of male and female participants; (b) school level, in order to have participants from the two cohorts that are generally served within programs (middle and high school); (c) geographic location, in which students of the two of the most populated regions in Chile were selected. A further description of students' characteristics can be found in Table 1.

Table 1. Characteristics of the sample.

\begin{tabular}{cccccc}
\hline Name & Sex & Age & Grade (at 2nd Year of Study) & Region & IVE-SINAE \\
\hline Eduardo & $\mathrm{M}$ & 16 & 11 th & Valparaíso & $90.73 \%$ \\
María & $\mathrm{F}$ & 17 & 11 th & Valparaíso & $88.38 \%$ \\
Silvia & $\mathrm{F}$ & 17 & 11 th & Valparaíso & $88.54 \%$ \\
Damaris & $\mathrm{F}$ & 17 & 11 th & Metropolitana & $73.74 \%$ \\
Marcos & $\mathrm{M}$ & 16 & 11 th & Metropolitana & $79.91 \%$ \\
Sergio & $\mathrm{M}$ & 17 & 11 th & Metropolitana & $76.65 \%$ \\
Valeria & $\mathrm{F}$ & 13 & 8 th & Metropolitana & $78.01 \%$ \\
Francisco & $\mathrm{M}$ & 14 & 8 th & Valparaíso & $89.23 \%$ \\
Gonzalo & $\mathrm{M}$ & 13 & 8 th & Valparaíso & $89.23 \%$ \\
Konrad & $\mathrm{M}$ & 14 & 8 th & Valparaíso & $89.23 \%$ \\
Amparo & $\mathrm{F}$ & 13 & 8 th & Valparaíso & $95.03 \%$ \\
Fabiola & $\mathrm{F}$ & 14 & 8th & Valparaíso & $89.23 \%$ \\
\hline
\end{tabular}

Participants had already been identified as gifted by their extracurricular programs: nine by the Raven Standard Progressive Matrices Test and three using the WISC III, mainly for pragmatic reasons as these were the only instruments used to measure intelligence in Chile at the time (currently the WISC $\mathrm{V}$ is used in Chile). However, as stated previously, since there are no formal regulations regarding the identification of gifted students in the country, the predominant criteria for selection was gifted potential in low-income student populations that could be nurtured by the programs in their role of catalysts [11]. All the students in the sample were first identified by their schools using a checklist with criteria for giftedness in general and specific areas. Regarding test results, the cut-off percentile for the students who were identified using the Raven was 90. For those selected with the WISC III, the average full-scale score was 120 . 


\subsection{Instruments and Procedures}

All participants and parents were contacted at the beginning of the school year to explain the purpose of the research and the responsibilities associated with students' participation. Once consent and assent forms were collected from each participant, they were invited to an informational training session. The study was conducted in accordance with the Declaration of Helsinki, and the protocol was approved by the Ethics Committee of the University under the Project 11140480.

Instruments and artifacts used in the study are explained below according to different stages of the research:

The first stage was focused on photo-narratives and photo-elicitation. Each student was given a cellphone-Previously formatted with specific applications and blocked content-to capture information about their daily lived experiences with teaching using photographs and narratives (captions) for approximately six months. The objective of this stage was to understand the experiences these students highlighted, including how they faced different classes, their mood, particular events that were meaningful for them, and the activities they enjoyed. Each participant's school provided authorization to carry out this part of the study. A two-hour training session was conducted prior to the beginning of this stage to clarify the purpose of the investigation and to instruct students on how to take the photographs. Main topics of this training process are described in Table 2.

Table 2. Training session for participants.

\begin{tabular}{|c|c|}
\hline Procedures & Addressed Topics \\
\hline 1. Explanation of the research & $\begin{array}{l}\text {-Main purpose of the study. } \\
\text {-General and specific objectives. } \\
\text {-Students as researchers. }\end{array}$ \\
\hline 2. Cell phones & $\begin{array}{l}\text {-General usage. } \\
\text {-Blocked content. } \\
\text {-Use of the camera. } \\
\text {-Privacy settings. } \\
\text {-Creating an account and uploading pictures and narratives to the Evernote }(\text { platform. } \\
\text {-Applications for editing photos, including erasing or pixelating faces. } \\
\text {-Manual for the use of cell phones (in print, provided to each student). }\end{array}$ \\
\hline 3. Photo taking & $\begin{array}{l}\text {-Types of photos that are aligned with research purposes. } \\
\text {-Ethics and taking inadequate photos (e.g., private spaces, not covering other people's faces, etc.). } \\
\text {-Number of expected photos per week. }\end{array}$ \\
\hline
\end{tabular}

Students took photographs during their first school semester-usually 1-2 pictures per week with a caption and/or narrative explaining their content-and uploaded them to a private digital platform (cloud) which only the researchers could access. At the end of each academic semester (July/November), students were invited to a group-interview session where the researchers brought printed copies of the students' photographs. Group photo-elicitation interviews helped to promote discussion regarding particular events and also contributed to the understanding of students' lived experience [53]. Furthermore, during the group session, students were asked to elaborate tentative groupings of photographs by themes created by them (without a predefined framework) in order to finish the session with a selection of the most relevant topics. Because students were undergoing different stages of adolescence, the decision was made to conduct separate focus groups for middle school and high school students. A synthesis of the guiding questions used for the group sessions can be found in Table 3. 
Table 3. Guiding questions of focus group sessions.

\begin{tabular}{l} 
Questions \\
\hline From the pictures you took and your experiences within the classroom this semester/year: \\
-What were some important/critical events that happened? \\
-How was your relationship with your teachers? \\
-Can you give us examples of good classes? Bad classes? \\
-Which were your favorite classes? \\
-As a gifted student, which classes do you think helped/did not help with your learning? \\
-How did you get along with your friends, classmates?
\end{tabular}

The goal of the second stage was to perform phenomenological interviews with each participant. Two semi-structured interviews were conducted throughout the school year: one at the end of the first semester, and the other at the end of the academic year. In these interviews, questions were open-ended, trying to maintain the balance between the experience being narrated and the meanings associated with that experience [54]. The focus of the interviews allowed the interviewees to thoroughly describe and analyze their particular experiences retrospectively, trying to evoke feelings and thoughts that occurred during the described event to provide richness to the lived experience [55]. Questions that guided the interview process were piloted previously with a different group of gifted students to check for clarity and accuracy. These questions can be found in Table 4 .

Table 4. Guiding questions of interview sessions.

\begin{tabular}{l} 
Questions \\
\hline From your experiences within the classroom this semester/year: \\
-Think about a class that you really liked. Tell me what happened (activities, assessments, etc.). \\
-Think about a class that you did not enjoy. Tell me what happened (activities, assessments, etc.). \\
-Tell me about a time when you had a good experience with your classmates. \\
-Tell me about a time when you did not have a good experience with your classmates. \\
-Tell me about a time when you had a good experience with your teachers. \\
-Tell me about a time when you did not have a good experience with your teachers. \\
\hline
\end{tabular}

\subsection{Data Analyses}

All group and individual interviews were recorded in audio format and transcribed verbatim. Nvivo11(C) was used as a qualitative platform to both assemble and analyze the data that were collected through photographs and interviews. All data were stored on a computer with a password, and anonymity of participants was ensured with the use of pseudonyms.

\subsubsection{Trustworthiness}

Several triangulation techniques were conducted to ensure the credibility of the data analysis process: (a) method triangulation was achieved by gathering information from different sources-photographs, group discussions, and individual interviews; (b) participant checks were conducted with participants before starting each new (group or individual) interview, where emerging findings were discussed; and (c) investigator triangulation was achieved by having one researcher and two research assistants collecting and analyzing the data.

\subsubsection{Data Analysis Procedures}

Pre-coding schemes were built from research questions and from group photo-elicitation interviews, in which students were asked to organize the data into tentative groups that were meaningful to them (e.g., teachers). These schemes were the starting point for the open-coding procedure conducted by the researchers. The research team analyzed the first set of data conjointly and then separately. Meetings were held on a weekly basis to discuss the process of analysis and questions that arose 
during this process. Each researcher was also responsible for memo-writing, which helped to focus the discussion and allowed the team to solve critical issues. The open-coding process guided the first stage of analysis. Continuous analyses and saturation allowed for more focused and selective coding. This process led to final theoretical coding in which concepts were refined for better understanding of the main research questions.

\section{Results}

The group of students in the sample was very diverse in terms of interests and extracurricular activities; an individual profile of each participant has been displayed in Table 5, which describes personalities, individual characteristics, interests, and some aspects of their social and family contexts. All the names used are pseudonyms.

Table 5. Individual profiles of students in the sample.

\begin{tabular}{|c|c|}
\hline Name & Profile \\
\hline Eduardo & $\begin{array}{l}\text { Eduardo is a young man who is especially interested in Mathematics, Physics, and History. } \\
\text { He describes himself as a self-taught man. He enjoys learning through books and YouTube. } \\
\text { He likes creating and editing videos. He really enjoys speaking in public. }\end{array}$ \\
\hline María & $\begin{array}{l}\text { Maria is a female student highly interested in music who attends an artistic High School. She enjoys } \\
\text { playing classic guitar, cello, drums, and the accordion. Throughout the study she was undergoing a } \\
\text { family crisis due to her father being seriously ill. }\end{array}$ \\
\hline Silvia & $\begin{array}{l}\text { Silvia is a high school student who has an intense passion for writing. She writes both novels and short } \\
\text { stories. She also enjoys reading and wants to become an architect, but also would like to explore science, } \\
\text { particularly the topic of nanoscience. }\end{array}$ \\
\hline Damaris & $\begin{array}{l}\text { Damaris is a female teenager. She has many and multiple interests in diverse fields, but nowadays is } \\
\text { more focused on science, particularly genetics and research in molecular genetics. She has been highly } \\
\text { involved in political movements and regularly participates in girl scouts. }\end{array}$ \\
\hline Marcos & $\begin{array}{l}\text { Marcos is a young man who loves reading, especially science fiction books and comics. He also enjoys } \\
\text { science, with a particular interest in mathematics. He is part of the Mathematics Academy in his high } \\
\text { school. For his tertiary education, he wants to pursue something related to environmental science. }\end{array}$ \\
\hline Sergio & $\begin{array}{l}\text { Sergio is very interested in biology. He has a very intense scientific spirit, which he has demonstrated } \\
\text { from a very young age. Medicine is his passion, and since he was a child he loved to study anatomy and } \\
\text { physiology. He sees himself as a very competitive person and likes videogames. }\end{array}$ \\
\hline Valeria & $\begin{array}{l}\text { Valeria is a young lady who is very passionate towards reading, writing poems, drawing, knitting, and } \\
\text { sewing. She defines herself as 'hyperactive' but at the same time very perfectionist. She loves listening } \\
\text { to music during recess and observing her classmates interact. }\end{array}$ \\
\hline Francisco & $\begin{array}{l}\text { Francisco is a male student who has the highest grades of his class, always obtaining first places in } \\
\text { academics. He has been in several schools because of recurrent bullying episodes. He wants to become } \\
\text { a math teacher so he can share his passion with other people. }\end{array}$ \\
\hline Gonzalo & $\begin{array}{l}\text { Gonzalo is a quiet person. He does not communicate very much with adults. He is passionate about } \\
\text { science, particularly experimental science such as Physics and Chemistry. He also plays the piano. }\end{array}$ \\
\hline Konrad & $\begin{array}{l}\text { Konrad is a teenage boy with lots of energy. He demonstrates passion and interest in all his endeavors. } \\
\text { He enjoys applied mechanics and industrial processes. He considers himself very competitive and likes } \\
\text { to be challenged. }\end{array}$ \\
\hline Amparo & $\begin{array}{l}\text { Amparo loves dancing. She practices the Chilean dance, cueca, and competes in several championships. } \\
\text { She was a regional champion. She is very self-demanding and perfectionist with her academic results. } \\
\text { She also enjoys reading and biology. }\end{array}$ \\
\hline Fabiola & $\begin{array}{l}\text { Fabiola enjoys dance, especially flamenco and ballet. She creates her own choreographies. She also } \\
\text { enjoys drawing and spending time with friends. She would like to study Anthropology. }\end{array}$ \\
\hline
\end{tabular}

Results were rich and depicted a series of activities within and outside the classroom, as well as narratives and photos of specific experiences that affected students' learning while they were in their classes. These experiences have been grouped into three categories defined by themes that emerged: content knowledge, teaching strategies, and assessment practices. Representative photos for each theme and sub-theme can be found in Table 6. Similarly, a display of the qualitative data used to exemplify the findings of each section is depicted in Table 7. 
Table 6. Most representative photos for each theme and sub-theme.

\begin{tabular}{|c|c|c|c|}
\hline Themes & Sub-Themes & Photo 1 & Photo 2 \\
\hline Content Knowledge & - & $\begin{array}{l}\text { Silvia, Maths class What's the } \\
\text { point of learning that? Are we } \\
\text { going to be businesspeople? }\end{array}$ & $\begin{array}{l}\text { Fabiola, History class So fun to } \\
\text { read the book 'Mythology', it is } \\
\text { entertaining and great, I learn a } \\
\text { lot but I have to read too much. I } \\
\text { love history }\end{array}$ \\
\hline \multirow[t]{4}{*}{$\begin{array}{l}\text { Teaching and } \\
\text { Learning }\end{array}$} & $\begin{array}{l}\text { Meaningfulness and } \\
\text { Value }\end{array}$ & $\begin{array}{l}\text { Eduardo, Biology class Our } \\
\text { biology teacher tried to put into } \\
\text { practice a very new learning } \\
\text { technique. She made us learn a } \\
\text { song about mitosis (...) }\end{array}$ & $\begin{array}{l}\text { Silvia, unspecified class } \\
\text { Watching a movie that teaches } \\
\text { various values that only few } \\
\text { people have. This makes sense. }\end{array}$ \\
\hline & Teaching Strategies & $\begin{array}{l}\text { Fabiola, History class Task in } \\
\text { History class...I loved this } \\
\text { course, too bad it is over } \\
\text { (Hands-on activity) }\end{array}$ & $\begin{array}{l}\text { Eduardo, unspecified class The } \\
\text { class today was very different } \\
\text { from what we're used to. The } \\
\text { teacher made us sit in a circle } \\
\text { without a notebook (... ) I think } \\
\text { I learned more than being in a } \\
\text { 'normal' class }\end{array}$ \\
\hline & \multirow[t]{2}{*}{$\begin{array}{c}\text { Consideration of } \\
\text { students' interests and } \\
\text { preferences }\end{array}$} & & is a \\
\hline & & $\begin{array}{l}\text { María, Art class They give me } \\
\text { the opportunity at school to } \\
\text { experience all kinds of art } \\
\text { without having to pay a peso!" }\end{array}$ & $\begin{array}{l}\text { Fabiola, Art class I love Art } \\
\text { class, there's nothing cooler than } \\
\text { creating a music album cover }\end{array}$ \\
\hline
\end{tabular}


Table 6. Cont.

\begin{tabular}{|c|c|c|c|}
\hline Themes & Sub-Themes & Photo 1 & Photo 2 \\
\hline & Use of time & $\begin{array}{l}\text { Eduardo, Technology class Is } \\
\text { it acceptable that to make a } \\
\text { chart the teacher gives us } 4 \\
\text { periods? I would like not to } \\
\text { waste time on things I believe } \\
\text { I'll never use, and if I do use } \\
\text { them, I don't need } 4 \text { periods to } \\
\text { learn them, just five minutes }\end{array}$ & $\begin{array}{l}\text { María, Gym class We are only } 3 \\
\text { women in my course, so when the } \\
\text { gym teacher is missing, it is cool, } \\
\text { since we have another free space } \\
\text { to sing, share and play guitar in } \\
\text { the courtyard }\end{array}$ \\
\hline Assessment Practices & Lack of Challenge & $\begin{array}{l}\text { Eduardo, Technology class I } \\
\text { would like to be taught } \\
\text { something more complex (...) } \\
\text { than making simple data charts }\end{array}$ & $\begin{array}{l}\text { Silvia, unspecified class } \\
\text { Writing, writing and just } \\
\text { writing. This is too simple for me. }\end{array}$ \\
\hline & Types of Assessments & $\begin{array}{l}\text { Francisco, History class Our } \\
\text { tasks about the Earth's Interior } \\
\text { (Hands-on activity) }\end{array}$ & $\begin{array}{l}\text { Silvia, unspecified class I'm not } \\
\text { a fan of working in groups }\end{array}$ \\
\hline
\end{tabular}

Table 7. Qualitative data used to exemplify the findings.

\begin{tabular}{ccccc}
\hline $\mathbf{N}^{\circ}$ & Name & Source & Quote & Page \\
\hline 1 & Silvia & $\begin{array}{c}\text { Individual Interview 1, } \\
\text { 2nd year. }\end{array}$ & ...It's the same topic all year long ... & 8 of 17 \\
\hline 2 & Maria & $\begin{array}{c}\text { Individual Interview 1, } \\
\text { 2nd year. }\end{array}$ & $\begin{array}{c}\text { There are mixed courses. Now we have } \\
\text { saxophone, drums .. }\end{array}$ & 15 of 19 \\
\hline 3 & Maria & $\begin{array}{c}\text { Individual Interview 1, } \\
\text { 2nd year. }\end{array}$ & $\begin{array}{c}\text { What are logarithms for? } \\
\text { I don't get it ... }\end{array}$ & 8 of 19 \\
\hline 4 & Gonzalo & $\begin{array}{c}\text { Individual Interview 1, } \\
\text { 2nd year. }\end{array}$ & $\begin{array}{c}\text { He only made us draw about our } \\
\text { national holiday ... }\end{array}$ & 9 of 12 \\
\hline 5 & Silvia & Individual Interview 2, & $\begin{array}{c}\text { [The teacher] gave us a complete } \\
\text { 2nt year. } \\
\text { intuction and told us how to relate } \\
\text { what we were about to see ... }\end{array}$ & 19 of 31 \\
\hline
\end{tabular}


Table 7. Cont

\begin{tabular}{|c|c|c|c|c|}
\hline $\mathbf{N}^{\circ}$ & Name & Source & Quote & Page \\
\hline 6 & Valeria & $\begin{array}{l}\text { Individual Interview 2, } \\
\text { 2nd year. }\end{array}$ & $\begin{array}{l}\text { He said OK let's work in groups } \\
\text { and you have to write down... }\end{array}$ & 24 of 25 \\
\hline 7 & Eduardo & $\begin{array}{l}\text { Individual Interview 2, } \\
\text { 2nd year. }\end{array}$ & $\begin{array}{l}\text { The teacher said 'go, } \\
\text { ahead, improvise'... }\end{array}$ & 4 of 25 \\
\hline 8 & Francisco & $\begin{array}{l}\text { Individual Interview 1, } \\
\text { 2nd year. }\end{array}$ & $\begin{array}{l}\text { I need to be challenged. Because it's also } \\
\text { a challenge to learn new things ... }\end{array}$ & 11 of 14 \\
\hline 9 & Konrad & $\begin{array}{l}\text { Individual Interview 2, } \\
\text { 2nd year. }\end{array}$ & $\begin{array}{l}\text { I wanted the teacher to } \\
\text { give me another activity... }\end{array}$ & 7 of 20 \\
\hline 10 & Silvia & $\begin{array}{l}\text { Individual Interview 2, } \\
\text { 2nd year. }\end{array}$ & $\begin{array}{c}\text { I didn't go to his classes, because he } \\
\text { wouldn't do anything... }\end{array}$ & 13 of 31 \\
\hline 11 & Valeria & $\begin{array}{l}\text { Individual Interview 2, } \\
\text { 2nd year. }\end{array}$ & $\begin{array}{l}\text { In History we have two hours, we are } \\
\text { doing activities most of the time... }\end{array}$ & 5 of 25 \\
\hline 12 & Silvia & $\begin{array}{l}\text { Group Interview 1, 1st } \\
\text { year. }\end{array}$ & $\begin{array}{c}\text { For example, we had to do an activity of } \\
\text { some news... }\end{array}$ & 19 of 33 \\
\hline 13 & Fabiola & $\begin{array}{l}\text { Individual Interview 1, } \\
\text { 2nd year. }\end{array}$ & $\begin{array}{c}\text { I get bored with PowerPoint, so much } \\
\text { Power Point ... }\end{array}$ & 9 of 14 \\
\hline 14 & Konrad & $\begin{array}{l}\text { Individual Interview 1, } \\
\text { 2nd year. }\end{array}$ & $\begin{array}{c}\text { He gave us a sheet of paper and told us } \\
\text { we had to work on a cube... }\end{array}$ & 4 of 14 \\
\hline 15 & Sergio & $\begin{array}{l}\text { Individual Interview 1, } \\
\text { 2nd year. }\end{array}$ & $\begin{array}{c}\text { The tests do not have the difficulty I was } \\
\text { expecting }\end{array}$ & 3 of 20 \\
\hline 16 & Marcos & $\begin{array}{l}\text { Individual Interview 1, } \\
\text { 2nd year. }\end{array}$ & $\begin{array}{c}\text { They don't understand each person has } \\
\text { a different point of view ... }\end{array}$ & 16 of 25 \\
\hline 17 & Silvia & $\begin{array}{l}\text { Individual Interview 2, } \\
\text { 2nd year. }\end{array}$ & $\begin{array}{c}\text { They start grading us for everything. } \\
\text { For the notebook, for participating in } \\
\text { absurd things... }\end{array}$ & 9 of 31 \\
\hline 18 & Eduardo & $\begin{array}{l}\text { Individual Interview 2, } \\
\text { 2nd year. }\end{array}$ & $\begin{array}{c}\text { And the teacher said: you two, you're } \\
\text { working together... }\end{array}$ & 8 of 25 \\
\hline 19 & Francisco & $\begin{array}{l}\text { Individual Interview 2, } \\
\text { 2nd year. }\end{array}$ & $\begin{array}{l}\text { I liked it because it had everything. } \\
\text { Multiple choice questions... }\end{array}$ & 22 of 27 \\
\hline 20 & Eduardo & $\begin{array}{l}\text { Group Interview 1, 1st } \\
\text { year. }\end{array}$ & $\begin{array}{c}\text { She asked: 'how do you want me to do } \\
\text { the test...' }\end{array}$ & 2 of 22 \\
\hline 21 & Sergio & $\begin{array}{l}\text { Individual Interview 2, } \\
\text { 2nd year. }\end{array}$ & $\begin{array}{c}\text { We had an open-book test and questions } \\
\text { were very analytical ... }\end{array}$ & 10 of 23 \\
\hline 22 & Marcos & $\begin{array}{l}\text { Individual Interview 2, } \\
\text { 2nd year. }\end{array}$ & $\begin{array}{c}\text { For us, from eleventh grade, we got the } \\
\text { north of Chile... }\end{array}$ & 16 of 39 \\
\hline
\end{tabular}

\subsection{Content Knowledge}

This category referred to gifted students' experiences relating to what is taught, and the different topics addressed by the curriculum and the textbooks. The students perceived the contents of the Chilean curriculum with a feeling of stagnation, because it did not provide room for depth. Silvia, a high school student, struggled to find depth in the content delivered by her Language Arts teacher:

...It's the same topic all year long. We read something from the textbook, we do an activity, then the test...there is no progress. We move along units, but not the content. Each unit is only reviewing general ideas.

(Silvia, High School)

Maria, a high school student attending an Arts high school, was the only student from the sample having a fulfilling experience with content knowledge. This positive experience was related to the integration of different disciplines, and the possibilities provided by the structure of the curriculum, to rapidly advance toward more complex content: 
There are mixed courses. Now we have saxophone, drums, cello, everything. I am now experiencing classic guitar ... it is hard for me because I can play but reading is hard. But I'm excited. I'm motivated. And yes, courses are like that. They begin from basics, intermediate ... depending on which level you are. And we have specialized teachers, that's even better.

(Maria, High School)

\subsection{Teaching and Learning}

This category encompasses the different strategies used by teachers to deliver content knowledge and facilitate students' learning. It also describes how students in the sample perceived the impact of these strategies on favoring or hindering their own learning.

\subsubsection{Meaningfulness and Value}

The students in the sample considered the 'meaning-making' process teachers followed to connect content-knowledge from the classroom to their daily lives crucial for their learning. Students had high expectations regarding content knowledge and considered it critical for the teacher to connect this content to real-life facts. In this regard, Maria did not understand the added value of logarithms in her daily-life:

What are logarithms for? I don't get it. I won't go and buy bread with logarithms.

(Maria, High School)

Similarly, Gonzalo argued that the type of activity given by his Technology teacher during class time was meaningless:

He only made us draw about our national holiday. But that's not useful. Something really useful would be a trash bin so we can learn to recycle.

(Gonzalo, Middle School)

Students described some activities, such as field trips, as significant for the meaning-making process. During these activities the students, guided by the teacher, were able to 'see' the connection between content and real-life events, as demonstrated by the experience narrated by Silvia when her class visited the house of the Chilean poet Pablo Neruda, now a museum:

[the teacher] gave us a complete introduction and told us how to relate what we were about to see with the unit we were addressing. It was about how poets and artists were involved in politics. When we finished the visit, she asked questions and explained how Pablo Neruda was affected by political events in his time.

(Silvia, High School)

\subsubsection{Teaching Strategies}

Middle school students reported positive experiences with teaching strategies that centered around play, as well as hands-on and experiential activities. For example, activities involving movement and interpretation of different roles through dramatization were particularly highly regarded. Valeria narrated an experience in which the Language Arts teacher had the class actively participate to recreate their knowledge and ideas:

He said OK let's work in groups and you have to write down this and this. Once you're finished, you have to act as a mime to represent what you did. We had so much fun.

(Valeria, Middle School)

For high school students, the preferred learning strategies were open-ended activities without a predetermined structure, allowing them to develop their creativity and critical thinking. As Eduardo 
narrated, his Music teacher did not focus the class on delivering the content, but allowed students to freely explore:

The teacher said 'go, ahead, improvise'. Because we had to create a song with no lyrics for a story. So the teacher picked up a story, randomly, from a book. We got The Prodigal Son, the one that's on the Bible ... . and we had to musicalize that.

(Eduardo, High School)

For both groups, the notion of challenge associated with novelty emerged as important, especially relating to activities that allowed students to grasp more complex ideas or concepts as compared to the highly-predictable 'traditional' classes. Regarding this, Francisco said:

I need to be challenged. Because it's also a challenge to learn new things. I don't like being in Math learning the same addition, the same division, the same subtraction. I want new things. I want new topics.

(Francisco, Middle School)

Students also reported which teaching strategies prevented them from learning effectively, such as regular classrooms that offer fewer opportunities to rapidly progress and move to new content knowledge. Strategies like teaching to the average student and reproductive/repetitive activities were perceived to be unhelpful toward strengthening their potential. Konrad, a middle school student who was more physically active when bored, wanted his English teacher to understand he needed a faster pace:

I wanted the teacher to give me another activity, or something else to do, so I don't get bored, so I don't have to stand up.

(Konrad, Middle School)

Likewise, Sergio—a high school student—also needs 'more' from his Physics teacher:

I didn't go to his classes, because he wouldn't do anything. In one hour and a half he did only one exercise, and the rest of the time, nothing. Nothing at all.

(Sergio, High School)

\subsubsection{Consideration of Students' Interests and Preferences}

This topic refers to when the teacher consciously considered students' interests when preparing and delivering class activities. Positive experiences were mainly associated with teachers who considered individual preferences based on developmental stage. Valeria expressed this idea while describing the way her teacher really connected with her interests:

In History we have two hours, we are doing activities most of the time. We were [studying] the French Revolution and the teacher made us sing Lady Gaga, combining it with all the History content. All of us were listening, reading the lyrics, and all of us signing it. It was so simple and so catchy. This class was so much fun!

(Valeria, middle school)

Similarly, Silvia narrated an experience in which the teacher considered students' interests based on their age:

For example, we had to do an activity of some news, and the teacher told us to look for a topic of our interest, and during his explanations he mentioned things such as Starcraft, Age of Empire.

(Silvia, High School) 
On the other hand, teachers who did not consider students' interests and used 'inactive' strategies, caused frustration and boredom in students. Fabiola, who particularly liked visual materials, mentioned:

I get bored with PowerPoint, so much Power Point. When [the teachers] put only letters and no drawings. No images are boring. I like drawings. I don't like reading books. I don't like it.

(Fabiola, middle school)

\subsubsection{Use of Time}

This aspect was probably one of the most critical issues experienced by students throughout the study because they constantly felt that they had excessive extra time during their school day. These waiting periods happened in different circumstances; however, the most salient moments were during class time, when students finished their activities before the rest of the group, showing that the planned activities did not consider individual students' characteristics and their working pace. To depict this situation, Eduardo provided a photograph of an organizational chart that he made in a Technology class with a caption that reflected his anger (Table 6, Use of Time, Photo 1).

Another waiting situation happened with the absence of teachers on a particular day or class, resulting in long periods of 'free' or 'dead' times. These occasions led students to question what to do with their time. To fill this void, some students engaged in productive and/or creative tasks in which they could deliver a certain product, such as a song or poem, like Maria's picture called 'creating new songs' (Table 6, Use of Time, Photo 2). On other occasions, free time was used for leisure activities enjoyed by them, such as listening to music or playing cards with their friends.

\subsection{Assessment Practices}

This category refers to the format of evaluation practices used by teachers during several occasions. Students from the study narrated their experiences with different kinds of assessments and how these tests affected them.

\subsubsection{Lack of Challenge}

Many students felt that the evaluation practices were excessively simple and did not challenge them, emphasizing memorization and attention to superficial details rather than the content knowledge:

He gave us a sheet of paper and told us we had to work on a cube. I finished right away because it was copy-paste.

(Konrad, Middle School)

For other students, the level of difficulty of the evaluations was just not high enough:

The tests do not have the difficulty I was expecting.

(Sergio, High School)

In the Social Sciences, teachers did not allow personal interpretations or contributions in their assessment practices:

They don't understand each person has a different point of view. History is like each historian wrote it. So she can't say it's wrong just because is the way we understood, because depending on the book you read, History changes.

(Marcos, High School)

Likewise, Silvia noted that her teachers considered grades to be more important than the assessment of knowledge and skills, emphasizing the summative part of the evaluation process rather than the formative one: 
They start grading us for everything. For the notebook, for participating in absurd things ...

(Silvia, High School)

\subsubsection{Types of Assessments}

While considering different evaluation methods, high school students noted a dislike for group projects because groups were selected arbitrarily, without considering ability level:

And the teacher said: you two, you're working together. I hate that. I don't like group projects because some students are mediocre and do nothing. I prefer to work individually.

(Eduardo, High School)

Few experiences were narrated by students regarding positive evaluation activities that presented variety and choice as its main components. For Francisco, a good test had to include a variety of question styles:

I liked it because it had everything. Multiple choice questions, open questions, problem-solving activities.

(Francisco, Middle School)

Students rarely reported experiences where the teacher provided students with the opportunity to choose the type of assessment they wanted. Eduardo was the only student who reported experiencing this assessment practice:

She asked: 'how do you want me to do the test, like this or like that?' and the teacher allowed us to vote, and we had many options.

(Eduardo, High School)

The most salient assessment experiences seen as positive were those that asked students to be more analytical rather than merely reproducing content knowledge. Throughout Sergio's narrative, open-book evaluations were seen as invaluable:

We had an open-book test and questions were very analytical. We could contend our answers ( ... ) ii is not like remembering the most important facts and making a conclusion, but to analyze why the writer wrote the book the way she did. And our performance was great, because the teacher said our answers were comparable or even better than college students.

(Sergio, High School)

Students also valued open-ended and creative assessments, viewing choice as an opportunity for flexibility:

For us, from eleventh grade, we got the north of Chile. And we chose mining. So we got to build a mine within the classroom.

(Marcos, High School)

\section{Discussion}

The purpose of this study was to explore how gifted students cope with their daily lives in regular schools as learners, focusing on the impact of the diverse teaching experiences they experience in regular classrooms on them as gifted learners.

\subsection{The Intersection between Students' Learning Needs and Their Academic Experiences}

In light of the results of this study, it is relevant to emphasize and contextualize the background of the participants: students in a country with no specific laws to address giftedness within regular schools and where efforts are mainly focused on implementing curriculum in such a way that improves 
schools' scores on national standardized tests [56]. In this scenario, students' learning needs are balanced with the teaching process that occurs in the regular classroom, which is directed toward the 'average' student; however, for the students in the sample, teaching sometimes is perceived differently.

In this study, students' needs, preferences, interests, and characteristics were quite diverse, which reflects the fact that the study did not consider one single profile of giftedness (i.e., a specific result on a given test). Rather, the common ground for this group was potential that could be manifested in different domains. Student needs and preferences can also vary through time, especially if talent is understood as a continuum of permanent growth [11]. However, these students unanimously present eagerness for learning; they always want more, and fast. To fulfill these needs, students expect and demand a pedagogy that can act as an environmental catalyst within their educational growth process [11]. This particular group of students preferred teaching strategies like open-ended tasks (more salient in high school) and hands-on activities (middle school). These preferences are consistent with what has been found by several authors [23,30-32] and age differences may be attributed to what developmental milestones have been reached in both groups. However, it was not the goal of this research to analyze these preferences in a comparative manner.

As found by Kanevsky [23], some of the most prevalent preferences such as problem-solving and preference toward complexity may also arise from students' familiarity with these types of activities from their existing gifted programs. Some programs, however, are specifically catering to the needs of gifted students. Within schools, the most common strategies used today can be found in the literature related to effective teaching [57]. Nevertheless, an effective strategy might not be enough for gifted students' learning, as differentiation is needed, but seldom used, in regular classrooms to better serve students' learning styles [58]. Although effectiveness was not considered or measured in this research, students revealed which strategies used by their schools and teachers they found most helpful and enjoyable, which match the above-mentioned strategies.

\subsection{Students' Views on What Is Taught}

Regarding the content knowledge that teachers address in regular classrooms, students do not feel connected to the national curriculum, as it is not challenging enough or fast enough to meet their needs. Students constantly felt they were learning 'more of the same', a feeling emphasized particularly by gifted secondary students who have a more critical stance on the educational system than their elementary peers. This feeling is consistent with previous findings on Chilean gifted populations, which have found feelings of incongruity and stagnation with the national curriculum [18]. Gifted students expressed a desire to achieve more depth than what is presented to them, showing concerns about the superficiality and lack of complexity in the written curriculum, a characteristic that is unique to this group as compared with 'regular' students [23].

\subsection{Students' Experiences with How They Are Taught}

Perceptions of the implementation of the curriculum are different between age groups. Middle school students prefer hands-on experiences, which is in line with previous results from this age group [31,32]. High school learners have a preference toward open-ended activities with no predetermined answer [23-29]. The interest in new challenges is also present in both groups [29,31,33,34]. Notably, challenge is not associated with complexity, but with novelty. This finding means that gifted students can feel challenged by new content and a different pedagogical strategy because it places them in a new learning scenario that is not 'more of the same'. However, as noted previously, these novel strategies do not always occur in schools and do not necessarily reflect an effective teaching process for the gifted because of the existing gaps in the school system regarding: (a) teachers' knowledge and preparation on giftedness; (b) educators' awareness that they have gifted students in their classrooms; (c) legal provisions at the school level that are exclusive for gifted students.

The use (or misuse) of time during teaching experiences is a common topic among gifted students. These students especially noted a lack of opportunity to progress while stuck in a classroom focused on 
teaching to the average student. As a result, students are faced with numerous 'dead times' within their regular classrooms, which they perceived as negative for their progress through content knowledge, although these times could turn into productive tasks in which other skills could be displayed. Therefore, waiting does not always translate into boredom: these gaps can become opportunities for creating different projects [25].

Finding meaning in daily classroom tasks and activities is hard for this group of students, who show a profound urge for connection with real-life events. This interest accounts for a need to not only 'absorb' theory, facts, and concepts, but also to contextualize this knowledge within their understanding of the world. As conceptualized by Siegle and McCoach [27], there is a lack of utility value present in the implemented teaching strategies, meaning that teachers do not regularly explain the purpose and/or benefits behind specific content areas. It is very common that Chilean teachers remain very attached to the prescribed curriculum, teaching from the textbook without considering students' backgrounds [44].

\subsection{Students' Stances on Evaluation Practices}

One of the most common-mostly negative-experiences that gifted students faced in the regular school system was the practice of assessments and evaluations. Students are persistently faced with assessments that are not authentic and tests that require a single, closed answer focused on memorization. Therefore, students feel no real challenge and also note that their personal views and/or opinions are punished by teachers rather than encouraged. This point is particularly concerning, considering that these students are in a critical developmental stage for the construction and transformation of worldviews is critical [59].

The assessment experiences seen as positive were those that provided students with opportunities to face open-ended tasks through problem-solving activities. Students also valued having options for how to demonstrate their learning, which highlights the importance of choice in the context of assessments [23]. This finding confirms the work of authors in the field who have stressed the importance of challenge, critical thinking, and open-ended tasks when performing evaluations directed toward gifted students [21,35-38].

\section{Limitations and Suggestions for Future Studies}

As in any qualitative study, the sample size for this study was small and specific to a region and country; therefore, it may be necessary to observe whether these findings are similar across different groups of gifted students. Another limitation is that students in the sample were part of an extracurricular gifted program, which may have acted as a 'safety-net' to poor mainstream educational experiences and may have affected their well-being as learners. Additionally, participating students had experiences that were particular to certain school contexts, which could vary in other academic settings that have different teaching and learning experiences. Therefore, it would be valuable to consider other school compositions for further studies. Finally, the identification procedures were not homogenous for the entire sample, which can translate into different profiles or expressions of giftedness that can impact how teaching and learning events are experienced.

Considering the aforementioned limitations, new cross-cultural research must be pursued in a way that considers the different ways that giftedness manifests itself and how the educational systems respond to these characteristics. It would also be relevant to consider gifted students who have never been served at the school level or experienced any type of intervention and explore and analyze their perspectives on schooling.

Additionally, it is essential to deepen this discussion by following these school experiences throughout the school grades to define commonalities in the experiences of gifted students throughout their formal education. These results would be particularly interesting because they may present an opportunity to paint a more accurate picture of the challenges that gifted students face in formal 
education both pedagogically and emotionally, and to contribute to the educational policies regarding giftedness and its development in regular schools.

\section{Conclusions and Practical Implications}

Positive school experiences surrounding teaching and learning can vary enormously between students. For some, positive experiences arise from having fun in their classes. Others prefer leisure moments throughout the school day. In fact, the experiences and preferences of gifted students might seem very similar to those of typical students in a classroom; however, for these students, a single trait stands out: a tireless passion toward learning. Throughout this study, it was possible to see that this flame can be easily extinguished but can also be ignited when adequately nurtured. Therefore, providing gifted students opportunities to feel satisfied and enjoy their daily lives at school is critical, as it is a response to the overarching purpose of education itself.

In countries like Chile, in which no official national policies exist regarding gifted education and teacher preparation for the gifted, listening to students' voices can become a significant and valid way to inform and modify current school practices. It is essential to acknowledge the rigidity of the curriculum while also making changes in how it is implemented in order to introduce pedagogical practices that can have a real and concrete impact. In this sense, in an unfavorable regular classroom scenario where no special accommodations are made for gifted students, some practices-which are already effective for all students—can be adapted and improved to meet the needs of gifted students. The highlights provided by students in this study target several of these practices:

- Teachers' efforts to implement adequate, student-centered teaching strategies are always appreciated and valued, as they can provide unique opportunities for gifted students to engage with learning in a challenging way. Activities, such as hands-on experiences and open-ended tasks, can be paired with a problem-based learning approach, giving preference to open-ended problems.

- Teacher attempts to consider age appropriate interests is also highly valued as part of the learning process. Individual preferences of gifted students need to be catered for an optimal learning process, for example, through pre-assessment or exploratory activities.

- If students are going to be provided with more content knowledge, this has to be paired with more opportunities to develop complex ideas. For example, it is not enough to provide students with another worksheet on the same topic. They need to be capable of advancing toward more intricate knowledge through investigation, case studies, project-based learning, etc.

- Gifted students' do not pursue knowledge in an encyclopedic way. Learning does not occur in a void. If meaning is not provided or activities not connected to real-life events, students will likely lose interest and motivation.

- All students in classrooms experience waiting times. For gifted students, these waits can also be productive moments that can be translated into real opportunities to develop complex products or ideas. Instructors can take advantage of these times to ask gifted students to freely create products associated with what is being taught and link them to their interests.

- Assessment does not have to be traditional and similar to standardized tests that are already known and repeated endlessly by students. It is important when working with this population to consider challenges and providing choice when facing evaluation tasks.

Author Contributions: Funding acquisition, M.P.G.-A.; Investigation, M.P.G.-A., M.V.-L., H.C.-H. and T.P.H.; Methodology, M.P.G.-A.; Writing—original draft, M.P.G.-A., M.V.-L. and H.C.-H.; Writing—review \& editing, T.P.H. and M.L.C.-S. All authors have read and agreed to the published version of the manuscript.

Funding: This research was funded by FONDECYT, grant number 11140480.

Conflicts of Interest: The authors declare no conflict of interest. 


\section{References}

1. Bain, S.K.; Bliss, S.L.; Choate, S.M.; Brown, K.S. Serving children who are gifted: Perceptions of undergraduates planning to become teachers. J. Educ. Gift. 2007, 30, 450-478. [CrossRef]

2. Burgos, C. Indagación metodológica creativa para el desarrollo de estrategias metacognitivas en estudiantes con talento académico. Int. J. Dev. Educ. Psychol. 2014, 2, 163-176. [CrossRef]

3. Arancibia, V. La educación de alumnos con talentos: Una deuda y una oportunidad para Chile. Temas De La Agenda Pública: Vicerrectoría De Comun. Y Asun. Públicospontificia Univ. Católica De Chile 2009, 26, 3-15.

4. Blumen, S. Motivación, sobredotación y talento: Un desafío para el éxito. Rev. Psicol. (Lima) 2008, 26, 149-186.

5. Götz, T.; Frenzel, A.; Haag, L. Ursachen von Langweile im Unterricht. Empir. Pädagogik 2006, 20, 113-134. [CrossRef]

6. Cross, T.L. Psychological and social aspects of educating gifted students. Peabody J. Educ. 1997, 72, $180-200$. [CrossRef]

7. Preckel, F.; Götz, T.; Frenzel, A. Ability grouping of gifted students: Effects on academic self-concept and boredom. Br. J. Educ. Psychol. 2010, 80, 451-472. [CrossRef]

8. Conejeros-Solar, M.L.; Sandoval-Rodriguez, K.; Gomez-Arizaga, M.P. Chile: The challenges of identification. Var. 2E 2018, 1, 10-12.

9. Behrend, A.H. Self-Perceptions of Gifted Achievers and Underachievers: A Phenomenological Study. Ph.D. Thesis, Liberty University, Lynchburg, Virginia, 2012.

10. Peterson, J.; Duncan, N.; Canady, K. A longitudinal study of negative life events, stress, and school experiences of gifted youth. Gift. Child Q. 2009, 53, 34-49. [CrossRef]

11. Gagné, F. Academic Talent development and the equity issue in gifted education. Talent Dev. Excell. 2011, 3, 3-22.

12. Thomson, D.L. Beyond the classroom walls: Teachers' and students' perspectives on how online learning can meet the needs of gifted students. J. Adv. Acad. 2010, 21, 662-712. [CrossRef]

13. Mills, C.J. Characteristics of effective teachers of gifted students: Teacher background and personality styles of students. Gift. Child Q. 2003, 47, 272-281. [CrossRef]

14. Oakland, T.; Joyce, D.; Horton, C.; Glutting, J. Temperament-based learning styles of identified gifted and nongifted students. Gift. Child Q. 2000, 44, 183-189. [CrossRef]

15. Gadanidis, G.; Hughes, J.; Cordy, M. Mathematics for gifted students in an arts-and technology-rich setting. J. Educ. Gift. 2011, 34, 397-433. [CrossRef]

16. Johnsen, S.K. Definitions, models, and characteristics of gifted students. In Identifying Gifted Students: A Practical Guide; Johnsen, S.K., Ed.; Prufrock Press: Waco, TX, USA, 2004; pp. 1-22. ISBN 9781593630034.

17. Yee, H.C.; Myers, B. Leaving gifted students behind: The misplaced public policy of deference to local officials in the public schools of the United States. In Proceedings of the 2nd Annual International Conference on Law, Regulations and Public Policy (LRPP 2013), Singapore, 17-18 June 2013.

18. Gómez-Arizaga, M.P.; Conejeros-Solar, M.L.; Martin, A. How good is good enough? A community-based assessment of teacher competencies for gifted students. SAGE Open 2016, 6. [CrossRef]

19. Tomlinson, C.; Brighton, C.; Hertberg, H.; Callahan, C.; Moon, T.; Brimijoin, K.A.; Conover, L.; Reynolds, T. Differentiating instruction in response to student readiness, interest, and learning profile in academically diverse classrooms: A review of literature. J. Educ. Gift. 2003, 27, 119-145. [CrossRef]

20. Yuen, M.; Chan, S.; Chan, C.; Fung, D.C.; Cheung, W.M.; Kwan, T.; Leung, F.K. Differentiation in key learning areas for gifted students in regular classes: A project for primary school teachers in Hong Kong. Gift. Educ. Int. 2018, 34, 36-46. [CrossRef]

21. Callahan, C.M.; Moon, T.R.; Oh, S.; Azano, A.P.; Hailey, E.P. What works in gifted education. Am. Educ. Res. J. 2015, 52, 137-167. [CrossRef]

22. Little, C.A. Curriculum as motivation for gifted students. Psychol. Sch. 2012, 49, 695-705. [CrossRef]

23. Kanevsky, L. Deferential differentiation: What types of differentiation do students want? Gift. Child Q. 2011, 55, 279-299. [CrossRef]

24. O’Reilly, C. Understanding gifted children. In School Guidance Handbook; National Centre for Guidance in Education: Dublin, Ireland, 2014; pp. 1-20.

25. Peine, M.E.; Coleman, L.J. The phenomenon of waiting in class. J. Educ. Gift. 2010, 34, 220-244. 
26. Rubenstein, L.D.; Siegle, D.; Reis, S.M.; McCoach, D.B.; Burton, M.G. A Complex quest: The development and research of underachievement interventions for gifted students. Psychol. Sch. 2012, 49, 678-694. [CrossRef]

27. Siegle, D.; McCoach, D.B. Making a difference: Motivating gifted students who are not achieving. Teach. Except. Child. 2005, 38, 22-27. [CrossRef]

28. Hidi, S.; Renninger, K.A. The four-phase model of interest development. Educ. Psychol. 2006, 41, 111-127. [CrossRef]

29. Kanevsky, L.; Keighley, T. To produce or not to produce? Understanding boredom and the honor in underachievement. Roeper Rev. 2003, 26, 20-28. [CrossRef]

30. Chan, D.W. Learning styles of gifted and nongifted secondary students in Hong Kong. Gift. Child Q. 2001, 45, 35-44. [CrossRef]

31. Pereira, N.; Gentry, M. A qualitative inquiry into the experiences of high-potential Hispanic English language learners in Midwestern schools. J. Adv. Acad. 2013, 24, 164-194. [CrossRef]

32. Samardzija, N.; Peterson, J.S. Learning and classroom preferences of gifted eighth graders: A qualitative study. J. Educ. Gift. 2015, 38, 233-256. [CrossRef]

33. Eddles-Hirsch, K.; Vialle, W.; McCormick, J.; Rogers, K. Insiders or outsiders: The role of social context in the peer relations of gifted students. Roeper Rev. 2012, 34, 53-62. [CrossRef]

34. Gallagher, J.; Harradine, C.C.; Coleman, M.R. Challenge or boredom? Gifted students' views on their schooling. Roeper Rev. 1997, 19, 132-137. [CrossRef]

35. Shoplik, A.L. Gifted Students in the Regular Classroom. Available online: http://www.cmu.edu/cmites/ giftedstudents.html (accessed on 23 November 2017).

36. Powers, E.A. The use of independent study as a viable differentiation technique for gifted learners in the regular classroom. Gift. Child Today 2008, 31, 57-65. [CrossRef]

37. Smutny, J.F. Teaching Young Gifted Children in the Regular Classroom. ERIC Digest E595. 2000. Available online: https://eric.ed.gov/?id=ED445422 (accessed on 31 January 2020).

38. VanTassel-Baska, J. Curriculum issues: Curriculum, instruction, and assessment for the gifted: A problem-based learning scenario. Gift. Child Today 2013, 36, 71-75. [CrossRef]

39. Erickson, F.; Shultz, J. Students' experience of curriculum. In Handbook of Research on Curriculum; Jackson, P.W., Ed.; MacMillan: New York, NY, USA, 1992; ISBN 978-002-900-385-5.

40. Cook-Sather, A. What would happen if we treated students as those with opinions that matter? The benefits to principals and teachers of supporting youth engagement in school. Nassp Bull. 2007, 91, 343-362. [CrossRef]

41. Mitra, D.L. The significance of students: Can increasing "student voice" in schools lead to gains in youth development? Teach. Coll. Rec. 2004, 106, 651-688. [CrossRef]

42. Rudduck, J. Student voice, student engagement, and school reform. In International Handbook of Student Experience in Elementary and Secondary School; Thiessen, D., Cook-Sather, A., Eds.; Springer: Dordrecht, The Netherlands, 2007; pp. 587-610. ISBN 9781402033667.

43. Gentry, M.; Rizza, M.G.; Owen, S.V. Examining perceptions of challenge and choice in classrooms: The relationship between teachers and their students and comparisons between gifted students and other students. Gift. Child Q. 2002, 46, 145-155. [CrossRef]

44. Sleeter, C.; Montecinos, C.; Jiménez, F. Preparing teachers for social justice in the context of education policies that deepen class segregation in schools: The case of Chile. In Teacher Education for High Poverty Schools; Lampert, J., Burnett, B., Eds.; Springer: Cham, Switzerland, 2016; Volume 2, pp. 171-191. ISBN 978-3-319-22059-8.

45. Contreras, D.; Flores, L.; Lobato, F.; Macías, V. Monetary Incentives for Teachers and School Performance: Evidence for Chile; Department Economy; University Chile: Santiago, Chile, 2003; Available online: https: //www.researchgate.net/profile/Lorena_Flores6/publication/44832375_Monetary_incentives_for_teachers_ and_school_performance_the_evidence_for_Chile/links/563219e008ae13bc6c372cee/Monetary--incentives-for--teachers--and--school--performance--the--evidence--for--Chile.pdf (accessed on 20 January 2020).

46. Ortiz, I. Escuelas inclusivas en el contexto de segregación social del sistema escolar chileno. Calid. En La Educ. 2015, 42, 93-122. [CrossRef]

47. Bertoni, E.; Elacqua, G.; Jaimovich, A.; Rodriguez, J.; Santos, H. Repositorio Ministerio de Educación del Perú Homepage. Available online: http://repositorio.minedu.gob.pe/handle/MINEDU/5969 (accessed on 18 January 2020). 
48. Conejeros, M.L.; Cáceres, P.; Riveros, A. Educación de Talentos Académicos en Chile: Una década de aprendizajes e investigación. In Investigación Orientada al Cambio en Psicología Educacional; Catalán, J., Ed.; Editorial Universidad de la Serena: La Serena, Chile, 2012; pp. 39-73. ISBN 978-956-7393-72-5.

49. Ministry of Education (Chile). Biblioteca del Congreso Nacional de Chile. Available online: https: //www.leychile.cl/Navegar?idNorma=266268 (accessed on 20 December 2019).

50. Henwood, K.; Lang, I. Qualitative Research Resources: A Consultation Exercise with UK Social Scientists; Economic and Social Research Council: Swindon, UK, 2003.

51. Holland, J.; Thomson, R.; Henderson, S. Qualitative Longitudinal Research: A Discussion Paper; London South Bank University: London, UK, 2006; ISBN 1874418-62-4.

52. Rodríguez, L.F.; Brown, T.M. From voice to agency: Guiding principles for participatory action research with youth. New Dir. Youth Dev. 2009, 2009, 19-34. [CrossRef]

53. Richard, V.M.; Lahman, M.K. Photo-elicitation: Reflexivity on method, analysis, and graphic portraits. Int. J. Res. Method Educ. 2015, 38, 3-22. [CrossRef]

54. Seidman, I. Interviewing as Qualitative Research: A Guide for Researchers in Education and the Social Sciences, 2nd ed.; Teachers College Press: New York, NY, USA, 1998; ISBN 978-080-773-697-5.

55. Petitmengin, C. Describing one's subjective experience in the second person: An interview method for the science of consciousness. Phenomenol. Cogn. Sci. 2006, 5, 229-269. [CrossRef]

56. Campos-Martínez, J.; Guerrero, P. Efectos indeseados de la medición de la calidad educativa en Chile. La respuesta de la sociedad civil. Cad. Cedes 2016, 36, 355-374. [CrossRef]

57. Ko, J.; Sammons, P.; Bakkum, L. Effective Teaching, 2nd ed.; Education Development Trust: Berkshire, UK, 2016; ISBN 978-1-909437-75-3.

58. Benny, N.; Blonder, R. Factors that promote/inhibit teaching gifted students in a regular class: Results from a professional development program for chemistry teachers. Educ. Res. Int. 2016, 2016, 1-11. [CrossRef]

59. Brizio, A.; Gabbatore, I.; Tirassa, M.; Bosco, F.M. "No more a child, not yet an adult": Studying social cognition in adolescence. Front. Psychol. 2015, 6. [CrossRef] [PubMed]

(C) 2020 by the authors. Licensee MDPI, Basel, Switzerland. This article is an open access article distributed under the terms and conditions of the Creative Commons Attribution (CC BY) license (http://creativecommons.org/licenses/by/4.0/). 